\title{
CHRONOMETRIC DATING AND LATE HOLOCENE PREHISTORY IN THE HAWAIIAN ISLANDS: A CRITICAL REVIEW OF RADIOCARBON DATES FROM MOLOKA'I ISLAND
}

\author{
MARSHALL WEISLER* \\ Department of Anthropology, DH-05, University of Washington \\ Seattle, Washington 98195
}

\section{INTRODUCTION}

The importance of chronometric dating in archaeology cannot be overemphasized. Indeed, most chronologies developed throughout the world during the past three decades have depended on radiocarbon age determinations to provide a temporal framework for examining change over time in cultural sequences during the late Pleistocene and Holocene. With the advent of legislation in the mid-1960s designed to protect archaeological sites in the United States threatened by increased urban development or government sponsored projects, archaeological surveys and excavations were mandated as a means for preserving information otherwise destroyed. As a result, thousands of projects have contributed to a growing body of "gray literature," $i e$, unpublished proprietary or manuscript reports with very limited circulation. Within these reports are hundreds, if not thousands, of ${ }^{14} \mathrm{C}$ age determinations, most of which are not accessible in published form. One objective of this paper is to present all the ${ }^{14} \mathrm{C}$ age determinations for the island of Moloka'i, Hawai'i as of December 1988, including 41 dates never before published with stratigraphic details.

Despite Polach's treatise on the limitations of ${ }^{14} \mathrm{C}$ dating in archaeology written over 10 years ago (Polach, 1976), the validity and utility of ${ }^{14} \mathrm{C}$ "dates" are most often accepted by researchers at face value. However, several recent critical examinations of ${ }^{14} \mathrm{C}$ data have produced some unsettling evaluations. Of fundamental concern is the relationship of the dated material to the actual archaeological event of interest (Butler \& Stein, 1988; Dean, 1978; Grayson, in press; Mead \& Meltzer, 1985). Other objectives of this paper are to critically review the significance of ${ }^{14} \mathrm{C}$ age determinations for Moloka'i, and to use these dates to outline the prehistoric sequence of the island. Although Kirch (1985) has provided a general summary of the prehistory of the Hawaiian Islands, the discussion that follows focuses on the ${ }^{14} \mathrm{C}$ data from the island of Moloka'i and critically evaluates their relation to stratigraphic context and archaeological significance.

Forty-eight age determinations are presented of samples collected and submitted for analysis between 1959 and 1988 (Fig 1). Forty-five are from archaeological sites, two from geologic contexts, and one is of modern marine shell dated to provide a correction factor for the ocean reservoir effect. Forty-three samples were charcoal (36 wood, 7 unspecified); other samples included marine shell (2), and one each of fishbone, coral and land snail. Most ${ }^{14} \mathrm{C}$ measurements were analyzed by Beta Analytic, Inc (41), 6

* Present address: Department of Anthropology, University of California, Berkeley, California 94720 


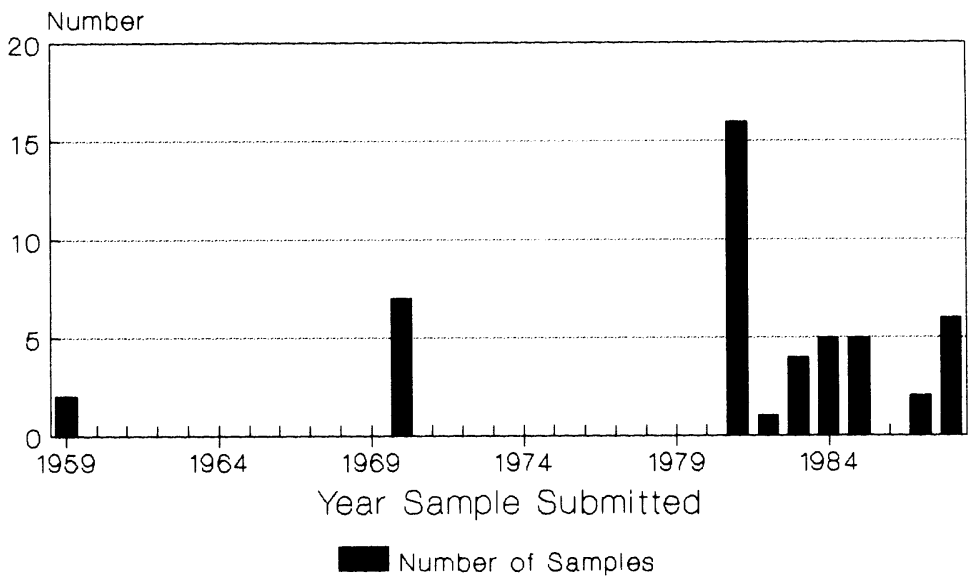

Fig 1. Bar graph of ${ }^{14} \mathrm{C}$ age determinations for the island of Moloka'i plotted by year submitted.

samples by Gakushuin, and 1 by Geochron Laboratories. The samples processed at the Gakushuin labs were dried and powdered, rootlets were removed by flotation, and the samples were boiled with $1 \mathrm{~N} \mathrm{HCl}$ solution for ca $1 \mathrm{hr}$ and washed with distilled water. No alkaline pretreatments were done (K Kigoshi, pers commun, 1988). As reported by Beta Analytic, all charcoal samples were given an extensive hot acid pretreatment to eliminate carbonates. After rinsing to neutrality, the pretreatment procedures were continued by submitting charcoal to hot alkali solution to extract humic acids. Again rinsing to neutrality, another acid treatment followed and another neutralization. Benzene syntheses followed and the dating proceeded normally in all cases. "Less than" dates are reported at $2 \sigma$. All age determinations from Gakushuin and Beta Analytic were reported as ${ }^{14} \mathrm{C}$ years BP (before AD 1950) with the half-life of ${ }^{14} \mathrm{C} 5568$ years. Calibrations for secular and marine reservoir effects were made on an updated microcomputer software program provided to the author by M Stuiver (Stuiver \& Reimer, 1986; Stuiver, Pearson \& Braziunas, 1986). Lab error multiplier factors are not available from any labs (cf Otlet, 1979; Stuiver, 1982). However, a recent detailed repetition study on a group of samples analyzed by Beta Analytic, in the 2000-yr range, indicated the error multiplier was close to 1 ( J Stipp, pers commun, 1988).

Prior to 1984, isotopic fractionation adjustments were not made on ${ }^{14} \mathrm{C}$ samples from Moloka'i. A conventional ${ }^{14} \mathrm{C}$ date (Stuiver \& Polach, 1977), however, must include a correction for isotope fractionation. Therefore, all samples are presented in Table 1 with ${ }^{13} \mathrm{C} /{ }^{12} \mathrm{C}$ data and conventional ${ }^{14} \mathrm{C}$ ages are used for calibrations when available. It is interesting to note that the ${ }^{13} \mathrm{C} /{ }^{12} \mathrm{C}$ corrections range from -55 to $+435 \mathrm{yr}$ and exhibit no consistent pattern. This alone should suggest caution when using any " ${ }^{14} \mathrm{C}$ age" determinations analyzed prior to 1984 for archacological sites from Moloka'i and probably all the Hawaiian Islands. It is also suggested 
TABLE 1

Isotopic fractionation adjustments for Moloka' ${ }^{14} \mathrm{C}$ determinations

\begin{tabular}{|c|c|c|c|c|c|c|}
\hline $\begin{array}{l}\text { Beta } \\
\text { no.* }\end{array}$ & Site/Locality & $\begin{array}{c}\text { "14 C age" } \\
\text { BP }\end{array}$ & ${ }^{13} \mathrm{C} /{ }^{12} \mathrm{C}$ & $\begin{array}{l}\text { Conven- } \\
\text { tional } \\
\text { tionage }\end{array}$ & $\begin{array}{c}{ }^{13} \mathrm{C} /{ }^{12} \mathrm{C} \\
\text { correction } \\
* *\end{array}$ & Reference \\
\hline 9275 & 03-312/Kalawao & $<120$ & -28.71 & $<120$ & $\mathrm{~N} / \mathrm{A}$ & $\begin{array}{l}\text { Somers, pers commun, } \\
1984\end{array}$ \\
\hline 9276 & 03-312/Kalawao & $900 \pm 70$ & -26.44 & $880 \pm 70$ & -25 & $\begin{array}{l}\text { Somers, pers commun, } \\
1984\end{array}$ \\
\hline 9962 & 03-312/Kalawao & $460 \pm 180$ & -23.28 & $490 \pm 180$ & +30 & $\begin{array}{c}\text { Somers, pers commun, } \\
1984\end{array}$ \\
\hline 11168 & 03-800/Kalama’ula & $220 \pm 60$ & -20.44 & $300 \pm 60$ & +75 & Athens, ms, 1985 \\
\hline 11169 & 03-800/Kalama’ula & $<120$ & -18.81 & $70 \pm 50$ & +100 & Athens, ms, 1985 \\
\hline 11170 & 03-800/Kalama’ula & $<190$ & -23.92 & $<190$ & $\mathrm{~N} / \mathrm{A}$ & Athens, ms, 1985 \\
\hline 11171 & 03-800/Kalama'ula & $170 \pm 70$ & -10.81 & $400 \pm 60$ & +230 & Athens, ms, 1985 \\
\hline 11172 & $03-800^{\prime} /$ Kalama'ula & $1000 \pm 60$ & +2.31 & $1450 \pm 60$ & +435 & Athens, ms, 1985 \\
\hline 13743 & 02-24/ Mo'omomi & $160 \pm 50$ & -12.65 & $360 \pm 50$ & +200 & $\begin{array}{l}\text { Dye, Weisler \& Riford, ms, } \\
1985\end{array}$ \\
\hline 13744 & 02-85/'Amikopala & $170 \pm 50$ & -19.58 & $260 \pm 50$ & +85 & $\begin{array}{l}\text { Dye, Weisler \& Riford, ms, } \\
1985\end{array}$ \\
\hline 20881 & $\begin{array}{l}\text { (0)-1610/Kawakiu } \\
\text { Nui }\end{array}$ & $160 \pm 60$ & -24.4 & $170 \pm 60$ & +10 & Weisler, ms, 1987 \\
\hline 20906 & 02-21/Kawa'aloa Bay & $1100 \pm 60$ & -13.7 & $1290 \pm 60$ & +180 & $\begin{array}{l}\text { Weisler \& Collins, ms, } \\
1988\end{array}$ \\
\hline $\begin{array}{l}27115 \\
27116\end{array}$ & $\begin{array}{l}\text { 03-885/Kipu } \\
\text { 03-885/Kipu }\end{array}$ & $\begin{array}{l}540 \pm 70 \\
640 \pm 60\end{array}$ & $\begin{array}{l}-24.4 \\
-26.6\end{array}$ & $\begin{array}{l}500 \pm 70 \\
610 \pm 60\end{array}$ & $\begin{array}{l}+10 \\
-25\end{array}$ & $\begin{array}{l}\text { Weisler, ms, } 1989 \\
\text { Weisler ms, } 1989\end{array}$ \\
\hline 27390 & 03-886/Kaunakakai & $370 \pm 70$ & -28.3 & $320 \pm 70$ & -55 & Weisler, ms, 1989 \\
\hline 27391 & 03-887/Kaunakakai & $600 \pm 110$ & -27.4 & $560 \pm 110$ & -40 & Weisler, ms, 1989 \\
\hline 27392 & 03-887/Kaunakakai & $30 \pm 60$ & -17.5 & $160 \pm 60$ & +120 & Weisler, ms, 1989 \\
\hline 27393 & 03-888/Kaunakakai & $380 \pm 80$ & -26.6 & $350 \pm 80$ & -25 & Weisler, ms, 1989 \\
\hline
\end{tabular}
bone)

* All wood charcoal samples except Beta-1 1172 (marine shell) and -20906 (marine fish-

$* *{ }^{13} \mathrm{C} /{ }^{12} \mathrm{C}$ correction calculated with $\left(\delta^{13} \mathrm{C}-25\right) 16$ (Stuiver, pers commun, 1988).

that solid carbon age determinations (Browman, 1981; Taylor, 1987) should be eliminated entirely from analysis of archaeological chronologies.

After a brief outline of Moloka'i prehistory, archaeological samples are reviewed from seven regions of Moloka'i beginning from the east end at Halawa Valley and working west (Fig 2). Within each region, oldest dates are generally discussed first. Figure 3 illustrates all the archaeological ${ }^{14} \mathrm{C}$ determinations for Moloka'i grouped by region and plotted at $1 \sigma$.

\section{A BRIEF OUTLINE OF MOLOKA'I PREHISTORY}

Centrally located in the Hawaiian archipelago, the elongated island of Moloka'i exhibits a striking array of ecological contrasts. Consisting of two broad shield volcanoes that overlap in the central saddle region, the eastern summit at Kamakou rises to $1244 \mathrm{~m}$ and hosts dense rain forests and extensive bogs which drain into large amphitheater-headed valleys along the windward coast. Halawa Valley typifies the windward coastal setting where fertile alluvial soils on broad floodplains were supplied with ample water for agriculture, and inhabitants had easy access to a range of marine resources. In this "ecologically favored" setting, the oldest habitations are found. The majority of Moloka'i, however, lies within a leeward rain shadow dominated by the $421 \mathrm{~m}$ high Maunaloa volcano, the summit of which lies amongst gently rolling grass-covered hills descending to moderately dissected slopes that terminate at rocky coastlines. Prehistoric settlements on West Moloka'i are located primarily at the summit region and around sheltered embayments along the coast. Unlike its windward coun- 


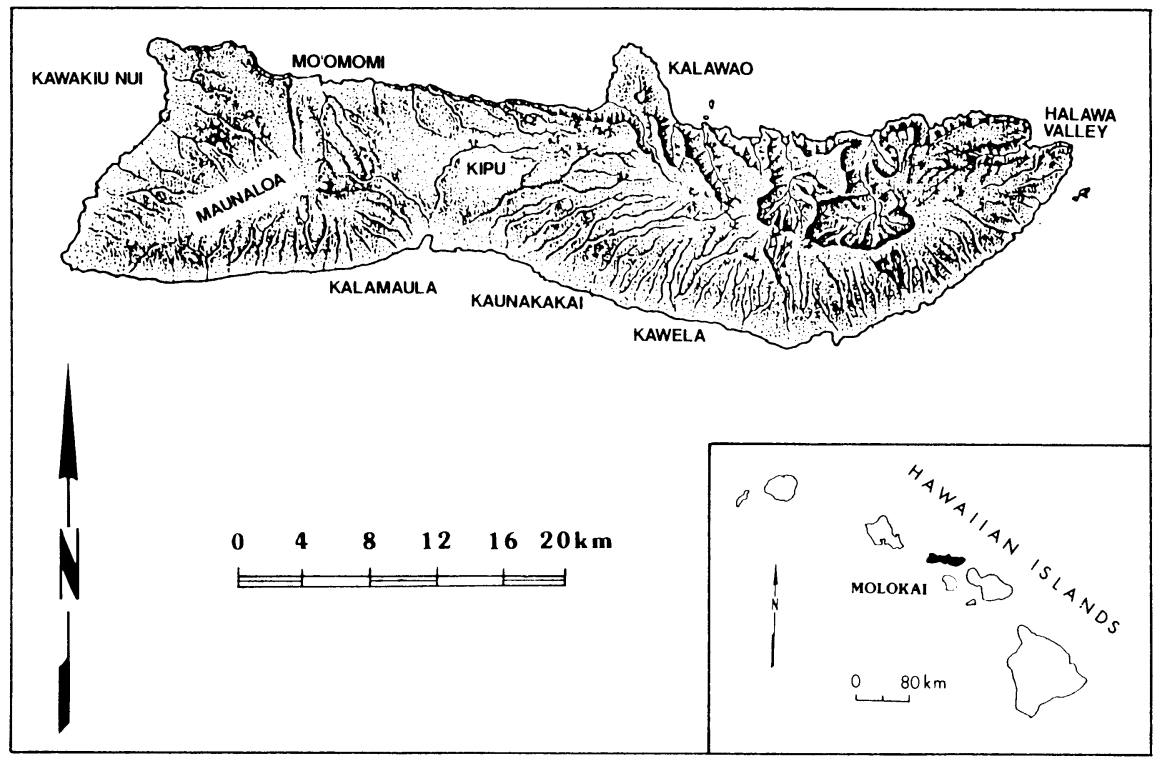

Fig 2. Map of the Hawaiian Islands showing the location of Moloka'i. Placenames on relief map refer to regions, discussed in the text, where ${ }^{14} \mathrm{C}$ age determinations are available.

terpart, population densities were much lower in the western, drier region of the island.

The discussion of Moloka'i prehistory that follows is modeled after historical periods proposed by Kirch (1985, p 298-308) for the archipelago as a whole, except that I have divided Kirch's Expansion period into an Early (AD 1 100-1400) and late Expansion period (AD 1400-1650) to reflect the addition of much new data for the longest period in the Hawaiian cultural sequence (Kirch, 1985, p 303). My discussion focuses primarily on temporal patterns of settlement to the exclusion of subsistence, economy and socio-political change throughout the cultural-historical sequence. Age determinations were grouped in historical periods by using the oldest cal AD date at $1 \sigma$.

Colonization Period (AD 300-600). Only eight sites throughout the archipelago contain cultural deposits dating to the earliest period of Hawaiian prehistory (Kirch, 1985, p 67-88). The data from these sites are from small excavated samples and are very incomplete. The composite picture documents settlement locations along the coastal, windward sides of the main islands. Halawa Dune, located on windward Moloka'i, is the only site on the island dating to this period. Marked by a sandy mound adjacent to the south bank of Halawa Stream and just inland from the boulder beach, portions of the lowest cultural stratum of the site date to the 6th century AD (Gak-2743) and contain postmolds, a pit and several amorphous hearths. Based on this scant evidence, house shape could not be discerned. Stone technology included adzes, percussion flaked basalt and volcanic glass. Fishing gear, as well as a range of faunal material, indicate a broadbased diet focused on marine subsistence and agriculture. The resident 


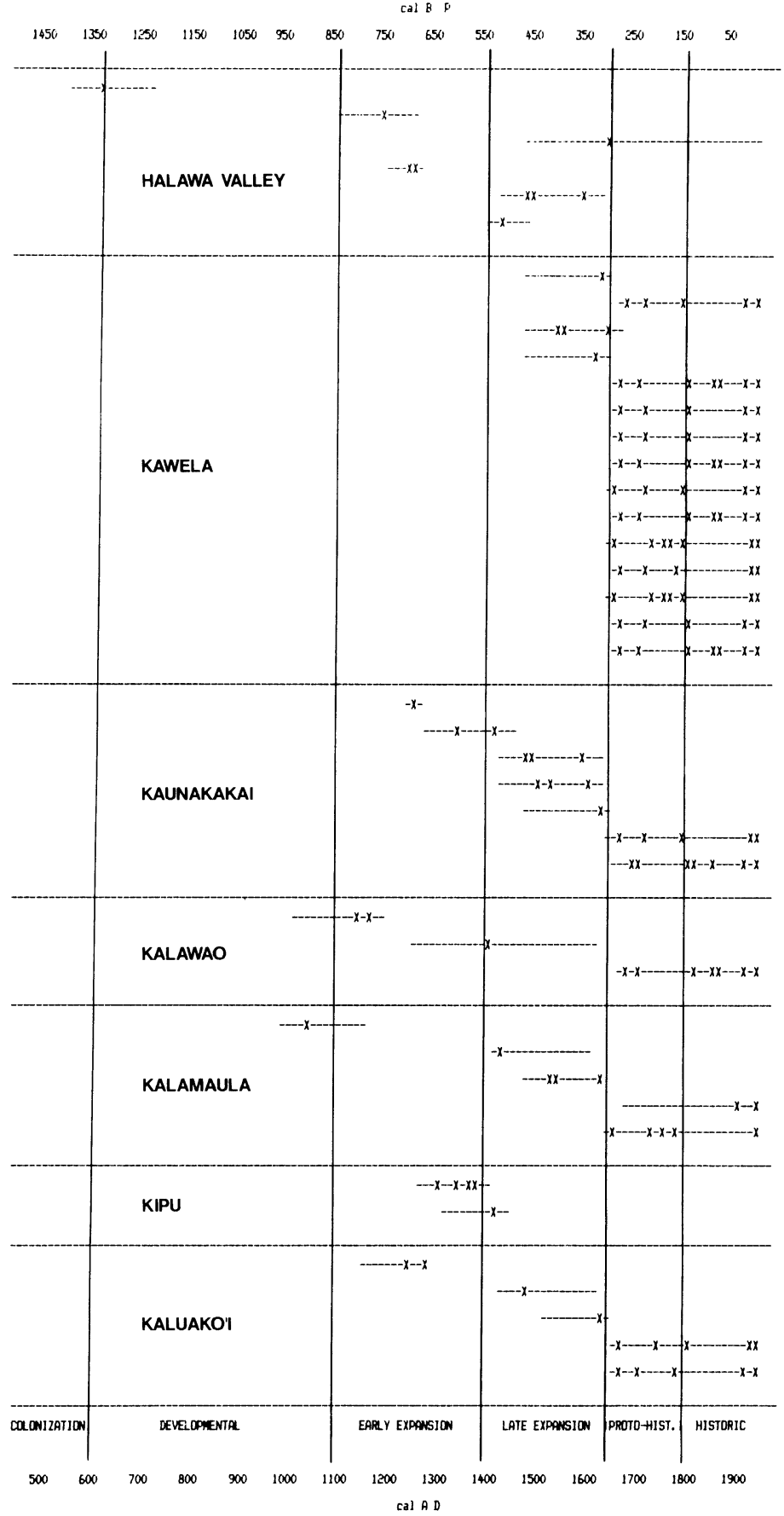

Fig 3. Archaeologic ${ }^{14} \mathrm{C}$ age determinations grouped by region and plotted at $1 \sigma$ by cultural-historical periods. Intercept points are marked with an "X." 
population is believed to have consisted of, at most, a few dozen inhabitants.

Developmental Period (AD 600-1100). Kirch (1985, p 302-303) describes this period as one in which distinctive patterns of Hawaiian material culture and economic adaptation were firmly established throughout the archipelago. Few settlements were established but population continued to increase. The first clear evidence of house types is present and the expansion of agricultural systems in windward settings may have occurred. Three sites from different regions of Moloka'i have been dated to the Developmental period. Occupations at the Halawa Valley dune locale seem to have been mainly in the form of small, round-ended houses of pole and thatch construction with internal stone-lined fireplaces. A permanent population was established with a broad-based economic pattern similar to older occupation levels (Kirch, 1975a).

At Kalawao on the windswept Kalaupapa Peninsula, a collapsed lava tube shelter (Kaupikiawa) was initially occupied by the 11 th century (Beta9276). Numerous hearths, dense concentrations of marine shellfish and the remains of coastal fish suggest temporary occupation of the shelter by small groups engaged in collecting invertebrates and fishing along the nearby rocky coast.

Situated in leeward central Moloka'i, $1.5 \mathrm{~km}$ from the south shore, is a complex of habitation structures and associated gardening features at Kalama'ula. A shell lens of food refuse from a large terrace was dated to the early 11 th century (Beta-11172) and 400 yr earlier than four wood charcoal samples from the same complex (Beta-11168 to-11171). If the early end of the age range is accepted, temporary gardening areas may have been established on the leeward slopes of Moloka'i ca $100 \mathrm{yr}$ before current archipelago-wide settlement models suggest ( $c f$, Hommon, 1986; Kirch, 1985).

Early Expansion Period (AD 1100-1400). The Expansion period, as defined by Kirch (1985, p 303-306; AD 1100 to 1600), is the best archaeologically documented temporal period for the Hawaiian cultural sequence. During this time, population levels increased at an unprecedented rate, expanding from their windward locales into the most arid, leeward environments. Dryland and irrigated agricultural systems were expanded and elaborated. The first kinds of aquacultural production (walled fish ponds built over broad, shallow reefs along the south coast) were invented, though few additions were added to the tool inventory which, by this time, was fairly standardized. For this period, $7{ }^{14} \mathrm{C}$ dates from Moloka'i are available from 6 sites throughout the island.

Beginning in the early 13 th century, burning for shifting cultivation on the colluvial slopes of Halawa Valley was first practiced and with it began localized human-induced environmental degradation (Gak-2744). The first evidence of temporary occupation along the leeward coast has been found in a sandy midden on the alluvial plain, east of Kaunakakai Stream and just inland from the shore (Beta-7564). From this locale, the broad reef-flat and its abundant marine resources were easily accessible, as were the inland expanse of fertile alluvial soil for agriculture. Dates for shifting cultivation above the flood plain begin by cal AD 1280 (Beta-27391), which currently is the oldest date for any dryland agricultural complex on the island. 
The first evidence for exploitation of marine resources (shellfish, fish and turtle) and land birds along the western half of the $\mathrm{N}$ coast date to the end of the 12 th century. Many middens along the $\mathrm{N}$ coast, between the Kalaupapa Peninsula and Mo'omomi, were probably occupied during this time. The Kaupikiawa shelter at Kalawao continued to be used by small groups.

At about the same time as the beginning of shifting cultivation in $\mathrm{Ha}$ lawa Valley, the upland forests at Kipu (335m asl) were cleared for dryland agriculture probably to feed an expanding population.

In sum, the Early Expansion period provides evidence for marine exploitation along the north and south coasts in leeward regions, and agricultural expansion into previously unoccupied areas such as Kaunakakai and Kipu.

Late Expansion Period (AD 1400-1650). Whereas the Early Expansion period is marked by temporary use of the remote leeward regions for resource acquisition, archaeological evidence suggests the occupation of these areas on a permanent basis during the Late Expansion period.

In Halawa Valley, permanent settlements were located $1.5 \mathrm{~km}$ inland from the coastal mound and the first residential complexes were inhabited (Gak-2740). The large-scale manufacture of adze blanks and preforms began by the mid-15th century (Beta-13743) at the Mo'omomi Adze Quarry on West Moloka'i, probably in response to the need for large adzes necessary for forest clearance for shifting cultivation. Permanent occupation of the Maunaloa summit region at the 'Amikopala Quarry complex was established by the early 16 th century (Beta-13744), but the association of this date with adze production is unclear. The 'Amikopala Quarry complex was unusual in Hawai'i as there was a full-time resident population engaged in agriculture and maintaining numerous house structures, field shelters and religious features spread over nearly 1500ha of the summit region. Only temporary use of distant quarries has been documented for other Hawaiian Islands (McCoy, 1977).

Firm evidence of intermittent dryland gardening was found on the leeward slopes of central Moloka'i above Kalama'ula. Several habitation terraces, a small shelter and numerous stone mounds resulting from field clearance are evident. Along the south coast at Kaunakakai, occupation continued at a sandy mound. Permanent residential complexes were located just inland from the coast, but these were destroyed during construction of the nearby town. (On the slopes just above the flood plain, small field shelters were occupied in the mid-15th century (Beta-27390, -27393) for tending dryland crops east of Kaunakakai Gulch.

East of Kaunakakai at Kawela, a similar sandy habitation mound was adjacent to the seaward edge of a broad alluvial plain. Occupation of this area for exploitation of marine foods and birds began by the late 15 th century AD. Permanent occupation of the Kawela uplands was indicated by evidence from two residential complexes.

During the Late Expansion period, a pattern of permanent occupation in the most arid regions of leeward Moloka'i and inland expansion within the windward valley of Halawa were documented by $14{ }^{14} \mathrm{C}$ dates at 12 sites. 
Proto-Historic Period (AD 1650-1795). The remaining $145 \mathrm{yr}$ of Hawaiian prehistory prior to European contact were documented during this period. Most archaeological age determinations from Moloka'i (18 of 44) dated to the Proto-Historic period and come from 14 sites, all in leeward areas. The Kawela area provided most of the data where a late prehistoric (17th and 18th centuries AD), nearly synchronic settlement pattern was intensively studied (Weisler \& Kirch, 1985). More than a dozen residential complexes were situated along ridge lines on either side of Kawela Gulch below the $40 \mathrm{~m}$ contour. Five of these, as well as a dryland agricultural complex and a rock shelter, dated to the Proto-Historic period.

Another sandy mound west of Kaunakakai Stream was also used at this time. Earlier occupation levels exist, but they have not been dated. The use of upland areas for shifting cultivation continued at Kaunakakai and Kalama'ula as well as exploitation of marine resources along the north coast at Kalawao and Mo'omomi. This was undoubtedly a sampling problem and earlier deposits must surely exist. However, the first documented use of the west coast was during this period at Kawakiu Nui (Beta-20881).

In summary, the oldest occupation on Moloka'i dates to the late Colonization period and is situated in a windward valley with easy access to inland and coastal marine resources. By the Developmental period, all the windward valleys were probably occupied, but the only documented occupation is a small, temporarily used shelter on the windswept Kalaupapa Peninsula. As population increased during the Early and Late Expansion periods, the leeward regions of the island were explored for food resources and fine-grained basalt for manufacture of adzes. Permanent occupation was established in leeward regions at the summit of Maunaloa, along the south coast at Kaunakakai, and in the interior of Halawa Valley. By the final centuries before European contact, all regions of the island were permanently occupied.

The prehistoric settlement of Moloka'i corresponds well to the model proposed by Kirch (1985) for the archipelago as a whole, although, based on present evidence, Kirch's Expansion period (AD 1100-1650) was divided here into Early (AD 1100-1400) and Late (AD 1400-1650) periods to reflect temporary, short-term use of the leeward regions of the island in the earlier period with permanent settlement in leeward regions not documented until the Late Expansion period ( $c f$, Kirch, 1985, p 303). When ${ }^{14} \mathrm{C}$ chronologies for other islands are evaluated, further refinements in the Hawaiian cultural-historical sequence may be possible and our understanding of Hawaiian prehistory enhanced.

\section{ARCHAEOLOGIC SAMPLES}

\section{Hawai'i}

\section{Moloka'i Island}

\section{A1-3, Halawa Dune site series}

Three wood charcoal samples coll from prehistoric cultural stratum (St $\mathrm{IV}$, ca $60 \mathrm{~cm}$ thick) of sandy habitation dune (A1-3;05-315) adjacent to $\mathrm{S}$ bank of Halawa Stream and immediately inland from boulder beach at $5 \mathrm{~m}$ 
asl ( $\left.21^{\circ} 9^{\prime} 42^{\prime \prime} \mathrm{N}, 156^{\circ} 44^{\prime} 33^{\prime \prime} \mathrm{W}\right)$. Site consists of two small, low mounds, erosional remnants of more extensive deposits (Kirch, 1975a, p 18). In 1969 and $1970,53 \mathrm{~m}^{2}$ was excavated, revealing in lowest cultural stratum, house foundations with internal slab-lined fireplaces, basalt adzes, abrading tools, bone fishhooks and other artifacts; also faunal material indicating broad-based diet based on marine subsistence and agriculture.

\section{Gak-2743. Halawa Valley}

$1380 \pm 90$

Wood charcoal from coastal midden Site A1-3 (05-315), Feature 57, Sq G3, Layer IV, $5 \mathrm{~cm}$ above Layer V, stratigraphically lowest date for site; charcoal concentration 5cm thick. Coll Aug 1969 and subm Jan 1970 by $\mathrm{P}$ Kirch (PK). Cal AD 582 (648) 759 at $1 \sigma$; cal BP 1368 (1302) 1191 at $1 \sigma$. Comments: beginning of Halawa Valley occupation sequence (Kirch, 1975b) and oldest habitation date for island. Weight of sample not reported.

\section{Gak-2741. Halawa Valley}

$820 \pm 80$

Wood charcoal, 13.0g, from Site A1-3 (05-315), Feature 48, Sq F5, assoc with structural foundation 2, 15-25cm deep, Layer IV; from fireplace outlined with water-rounded stones containing charcoal, ash, marine shell and bone. Coll Aug 1969 and subm Jan 1970 by PK. Cal AD 1131 (1219) 1277 at $1 \sigma$; cal BP 818 (731) 673 at $1 \sigma$. Comment: terminal occupation of Layer IV.

\section{Gak-2742. Halawa Valley}

Wood charcoal, 8.0g, from Site A1-3 (05-315), Feature 58, Sq G5, intrusive from top of Layer IV; earth oven filled with vesicular basalt, concentrated charcoal and ash. Coll Aug 1969 and subm Jan 1970 by PK. Cal AD 1494 (1656) 1955 at $1 \sigma$; cal BP 456 (294) 0 at $1 \sigma$. Comment: dates period of use at or after abandonment of site (Kirch, 1975a, p 32).

General Comment: A1-3 (05-315) coastal mound series provides initial occupation and abandonment dates for this important archaeological site and clearly identifies lower levels of St IV as earliest identified occupation on Moloka'i. Halawa Valley dates (including those described below) were originally reported by Kirch (1975b) and document one of only a few occupation sequences for Hawaiian Islands.

\section{Gak-2744. Halawa Valley}

$750 \pm 90$

Wood charcoal, $8.0 \mathrm{~g}$, from taluvial fan site, A1-4 (05-315), geol Unit $\mathrm{B}, 32.5 \mathrm{~cm}$ thick, stratum of hard-packed clay with charcoal and terrestrial gastropods (Kirch, 1975a, p 58). Coll Aug 1969 and subm Jan 1970 by PK. Cal AD $1211(1264,1268,1276) 1284$ at $1 \sigma$; cal BP $739(686,682,674) 666$ at $1 \sigma$. Comments: dates initial burning of valley slopes and beginning of human-induced erosion. Correlates with upper St IV occupation (Gak2741).

Gak-2739. Halawa Valley

$350 \pm 80$

Wood charcoal, $9.0 \mathrm{~g}$, from rock shelter and habitation terrace Site A 1-770 (05-315), Feature 3, mainly in Sq 4, intrusive to St III, 20-90cm below surface; sample from refuse pit filled with discrete ash lenses, char- 
coal, silty sediment, volcanic glass flakes, adze fragments and marine invertebrates. Coll 1969 by G Hendren and subm Jan 1970 by PK. Cal AD 1441 $(1494,1502,1506,1605) 1645$ at $1 \sigma ; \mathrm{cal}$ вР $509(456,448,444,345) 305$ at $1 \sigma$. Comments: average date for use of refuse pit and temporarily occupied shelter $1.3 \mathrm{~km}$ from coast (Hendren, 1975). Possible assoc with primary flexed human burial.

\section{Gak-2740. Halawa Valley}

$440 \pm 80$

Wood charcoal, 40g, from habitation terrace Site A1-790 (05-315), Feature 2, Sq F7 and G7, intrusive to St III, capped by St I, 50-60 cm below surface; earth oven filled with fire-cracked basalt, ash, charcoal, some marine shell, bone and one discrete ash lens. Coll Aug 1969 by Hendren and subm Jan 1970 by PK. Cal AD 1414 (1439) 1491 at $1 \sigma$; cal BP 536 (511) 459 at $1 \sigma$. Comment: site interpreted as a cookhouse and formed part of a residential complex situated $1.5 \mathrm{~km}$ from the coast (Hendren, 1975).

General Comment: temporary, inland occupation of the interior of Halawa Valley beginning during the Early Expansion period (AD 1 100-1650; Kirch, 1985 ) is indicated by Site A1-770 (Beta-2739), while cookhouse Site A1790 (05-315; Beta-2740), part of residential complex, suggests permanent occupation by early 15 th century.

\section{4-144, Kawela Mound series}

Kawela Mound is situated adjacent to seaward edge of broad alluvial plain and, at time of occupation, immediately W of Kawela Stream $\left(21^{\circ} 4^{\prime} 5^{\prime \prime}\right.$ $\left.\mathrm{N}, 157^{\circ} 0^{\prime} 0^{\prime \prime} \mathrm{W}\right)$. Site is marked by low sandy dune $15 \mathrm{~m}$ in diam and $1.5 \mathrm{~m}$ elev. From 8 major cultural and geol strata, total depth $>235 \mathrm{~cm}$, early human use of Kawela area, centered on exploitation of marine resources and birds, was documented (Weisler \& Kirch, 1985, p 150). Later strata correlate with upland sites occupied primarily during 17 th and 18 th centuries AD.

Beta-2278. Kawela

$$
290 \pm 60
$$

Wood charcoal, 20.5g, from coastal midden Site 04-144, Feature 17, $\operatorname{Tr} 2$, St VB, ca $235 \mathrm{~cm}$ below surface; earth oven filled with ashy sediment, charcoal, fire-cracked vesicular basalt, marine and brackish water mollusks and bone. Coll Oct 1980 by M Weisler (MW); subm Jan 1981 by PK and MW. Cal AD 1494 (1640) 1656 at $1 \sigma$; cal BP 456 (310) 294 at $1 \sigma$. Comment: although this is not lowest habitation level of site, it is earliest date of occupation for Kawela area. While dates, cal AD 1673, 1678 and 1739 were obtained for St III (Beta-2273), St VB date, at ca $235 \mathrm{~cm}$ below surface, is $>110 \mathrm{~cm}$ decper, making cal AD 1494 likely age of occupation. Bones of endemic Hawaiian goose (Nesochen sandvicensis; id by S L Collins), historically unknown from Moloka'i, were recovered from this level and may have been culturally deposited.

\section{Beta-2273. Kawela}

Wood charcoal, 9.1g, from Site 04-144, Tr 7, St III; scoop hearth filled with charcoal and ash. Coll Oct 1980 by MW; subm Jan 1981 by PK 
and MW. Cal AD $1673(1678,1739,1804,1938,1955) 1943$ at $1 \sigma$; cal BP $277(272,211,146,12,0) 7$ at $1 \sigma$. Comment: date for St III which contains densest concentrations of cultural material in site and correlates with settlement of inland residential complexes ( $c f$, Beta-2274 to -2277, -2279, -3362 to -3369$)$. Due to depth of St III $(105-160 \mathrm{~cm}$ below surface) and lack of any historic artifacts, cal AD dates of 1673, 1678, and 1739, assigned to Proto-Historic period (AD 1650-1795), are best age estimates of occupation.

General Comment: two cultural strata were dated from Kawela Mound, one near base of site, providing age for early use of area, the other ca 100$150 \mathrm{~cm}$ below surface which correlates with occupation of upland settlements.

\section{Upland Kawela series}

Thirteen dates document late prehistoric (17th and 18th centuries AD), nearly synchronic settlement pattern during Proto-Historic period. Samples coll during intensive survey of $7.7 \mathrm{~km}^{2}$ of leeward, s-central Moloka'i, including $442.5 \mathrm{~m}^{2}$ surface collection and excavation from 72 of 499 architectural features (Weisler \& Kirch, 1985). Ten samples are from residential complexes (Weisler \& Kirch, 1985, p 132). Two dates are from a dryland agric complex, and 1 sample was from an inland rock shelter. Eleven dates were originally reported as modern, $i e$, within $2 \sigma$ on the old side of modern standard (M Tamers, pers commun, 1986). Because no early historic artifacts were found in Kawela settlement area (aside from occasional late historic whiskey or wine bottle), all "modern" ages, reported here as "less than" $(<)$ yr BP at $2 \sigma$, are considered prehistoric.

\section{Beta-3364. Kawela}

$300 \pm 80$

Wood charcoal, 7.2g, from U-shaped enclosure Site 03-722 (Feature 408), architectural component 1 , Sampling St D, NE $1 / 4$ of Cell 8, intrusive to St IVA; earth oven filled with fire-cracked vesicular basalt, dense ash, charcoal, marine invertebrates and bone. Coll Mar 1981 and subm Sep 1981 by MW. Cal $1476(1532,1541,1637) 1659$ at $1 \sigma$; cal BP 474 (418, $409,313) 291$ at $1 \sigma$. Comment: near base of ridge, ca $175 \mathrm{~m}$ inland from coast at $21 \mathrm{~m}$ contour, residential complex 03-722 has only three structures. Complex may be distant extension of another residential complex located upslope, remnant of larger complex that was partially destroyed by bulldozing or small residential unit. Beta-3364 is slightly older than most upland residential complexes at Kawela.

\section{Beta-3365. Kawela}

$290 \pm 60$

Wood charcoal, 22.1g, from C-shaped shelter Site 03-724 (Feature 431), architectural component 1, Units 1 to 4, St II, 12-30 cm below surface; slab-lined oven filled with fire-cracked vesicular basalt, dense ash and marine invertebrates. Coll Mar 1981 and subm Sep 1981 by MW. Cal AD 1494 (1640) 1656 at $1 \sigma$; cal BP 456 (310) 294 at $1 \sigma$. Comment: date for cook-house and assoc residential complex. Feature 431 is 1 of 5 small shelters which surround large primary house structure. Residential complex, 
along with assoc shrine, $37 \mathrm{~m} \mathrm{E}$ of main group, is situated along narrow ridge just inland from coast. Younger range of date, within Proto-Historic period, is probably more precise for occupation, considering ages of other residential complexes at Kawela.

\section{Beta-2274. Kawela}

Wood charcoal, 25.2g, coll from Site 04-730 (Feature 119), from architectural component 1, Units J41 and J42, St I, 0-9cm below surface; earth oven filled with dense ash, dispersed charcoal, fire-cracked vesicular basalt, bone and marine invertebrates. Coll Oct 1980 by MW; subm Jan 1981 by PK and MW. Cal AD $1689(1694,1722,1812,1859,1869,1921$, 1955) 1926 at $1 \sigma$; cal BP $261(256,228,138,91,81,29,0) 24$ at $1 \sigma . \mathrm{Com}$ ment: date for use of cook-house.

\section{Beta-2275. Kawela}

Wood charcoal, 11.8g, from habitation terrace 04-730 (Feature 121), dispersed through Units J23, J24, K23, K24, E22 and F22, St I, 0-15cm below surface. Coll Oct 1980 by MW; subm Jan 1981 by PK and MW. Cal AD $1680(1685,1730,1808,1931,1955) 1937$ at $1 \sigma$; cal BP $270(265,220$, $142,19,0) 13$ at $1 \sigma$. Comment: provides second date for residential complex 04-730.

General Comment: 2 of 5 habitation structures comprising residential complex 04-730, C-shaped shelter (Feature 119) and habitation terrace (Feature 121), were situated along E rim of Kawela Gulch at $95 \mathrm{~m}$ contour overlooking gulch and S coastline. It was only residential complex in Kawela settlement with evidence of stone adze production. Beta-2274 and -2275 , which overlap at $2 \sigma$, suggest that separate structures comprising residential complex were occupied contemporaneously during Proto-Historic period. Site was subsequently destroyed by modern construction.

\section{Beta-2276. Kawela}

Wood charcoal, 11.1g, from habitation terrace Site 03-720, (Feature 321 ), architectural component 1 , Unit 1 , St I, $13-26 \mathrm{~cm}$ below surface, coll from earth oven filled with ashy sediment, fire-cracked vesicular basalt, marine shellfish and bone. Coll Nov 1980 by MW; subm Jan 1981 by PK and MW. Cal AD $1680(1685,1730,1808,1931,1955) 1937$ at $1 \sigma$; cal BP $270(265,220,142,19,0) 13$ at $1 \sigma$. Comment: nearly $1 \mathrm{~km} \mathrm{~W}$ of Kawela Gulch is largest residential complex in Kawela study area consisting of 33 habitation and religious structures, burial platforms and gardening mounds spread along $260 \mathrm{~m}$ of broad ridge. Sample coll from habitation terrace dated use of structure and, by assoc, residential complex.

\section{Beta-3363. Kawela}

Wood charcoal, 19.1g, from habitation terrace Site 04-142 (Feature 110), architectural component 1, Sampling St A, Cell 6, 22-25cm below surface; scoop hearth filled with marine invertebrates, fishbone, ash and dense charcoal lens at base. Coll Apr 1981 and subm Sep 1981 by MW. Cal AD $1689(1694,1722,1812,1859,1869,1921,1955) 1926$ at $1 \sigma$; cal BP $261(256,228,138,91,81,290) 24$ at $1 \sigma$. Comment: date for structure, 
substantial habitation terrace situated seaward of main residential complex.

\section{Beta-3366. Kawela}

Wood charcoal, 13.7g, from habitation terrace Site 04-142 (Feature 114), architectural component 1, Unit 1, below St I and above St V, 4$12 \mathrm{~cm}$ below surface; slab-lined fireplace containing ashy sediment with marine and freshwater invertebrates, fishbone, Aleurites sp seed endocarp and evidence of two separate firings. Coll Apr 1981 and subm Sep 1981 by MW. Cal AD $1665(1681,1735,1806,1936,1955) 1955$ at $1 \sigma$; cal BP 285 $(269,215,144,14,0) 0$ at $1 \sigma$. Comment: date for lowest of two firings in fireplace. Dates use of food preparation area as well as residential complex (cf, Beta-3363, -3367).

\section{Beta-3367. Kawela}

Wood charcoal, 21.5g, from terrace Site 04-142 (Feature 113), architectural component 2, Sampling St D, Cell 24, between St I and IV, 5$20 \mathrm{~cm}$ below surface; earth oven filled with fire-cracked vesicular basalt in ashy matrix. Coll Apr 1981 and subm Sep 1981 by MW. Cal AD 1689 (1694, $1722,1812,1859,1869,1921,1955) 1926$ at $1 \sigma$; cal BP $261(256,228$, $138,91,81,29,0) 24$ at $1 \sigma$. Comment: dates use of house structure as well as residential complex ( $c f$, Beta-3363, -3366).

General Comment: situated along E ridge of Kawela Gulch at $81 \mathrm{~m}$ contour is cluster of 6 habitation structures with another terrace $20 \mathrm{~m}$ downslope. Environmental setting, overlooking agricultural area with commanding view of S coastline and across to Lana'i, Maui and Kaho'olawe, and "impressive" architecture of structures, suggests high status residence. Older portions of Beta-3363, -3366 and -3367, which overlap at $2 \sigma$, are in ProtoHistoric period. Site complex is illustrated in Weisler and Kirch (1985, p 147).

\section{Beta-3368. Kawela}

Wood charcoal, 2.4g, from compound structure Site 03-717 (Feature 248), N 1/2, Sampling St A, Cell 1, St I, 3-12cm below surface; dispersed through St I. Coll Apr 1981 and subm Sep 1981 by MW. Cal AD 1667 $(1671,1747,1761,1770,1799,1944,1955) 1948$ at $1 \sigma$; cal вP $283(279$, $203,189,180,151,6,0) 2$ at $1 \sigma$. Comment: sample given extended counting time to reduce statistical error. Residential complex 03-717, consisting of 21 structural features, is $\mathrm{W}$ of Kawela Gulch, ca $600 \mathrm{~m}$ from coast at average elev of $35 \mathrm{~m}$. Beta-3368 provided date for largest, most impressive house feature not only in complex, but in entire Kawela settlement. Large quantities of marine shellfish, lithic debitage from tool manufacturing and artifacts are assoc with many structures. Occupation of site assigned to ProtoHistoric period.

\section{Beta-3369. Kawela}

Wood charcoal, 6.6g, from rectangular enclosure Site 03-732 (Feature 414), architectural component 1, Unit 1, St II, 2-16cm below surface; slablined fireplace with fire-cracked vesicular basalt. Coll Mar 1981 and subm 
Sep 1981 by MW. Cal AD $1670(1674,1743,1801,1941,1955) 1945$ at $1 \sigma$; cal BP $280(276,207,149,9,0) 5$ at $1 \sigma$. Comment: date for use of house feature, which was 1 of 6 structural features that comprised residential complex. Located ca $200 \mathrm{~m}$ from coast between $18-29 \mathrm{~m}$ elev, only sparse shellfish and lithic scatters are assoc with structures suggesting short-term use.

\section{Beta-2277. Kawela}

Wood charcoal, 9.9g, from square enclosure Site 03-731, (Feature 297), architectural component 1, Unit 11, St I, 2-12cm below surface; scoop hearth filled with dense ash. Coll Nov 1980 by MW; subm Jan 1981 by PK and MW. Cal AD $1667(1671,1747,1761,1770,1799,1944,1955)$ 1948 at $1 \sigma$; cal BP $283(279,203,189,180,151,6,0) 2$ at $1 \sigma$. Comment: dates use of shelter and assoc dryland agricultural complex.

\section{Beta-2279. Kawela}

Wood charcoal, 8.3g, from square enclosure Site 03-731, (Feature 296), architectural component 1, Unit 2, St I, 2-13cm below surface; scoop hearth filled with ashy sediment and charcoal concentration at base. Coll Nov 1980 by MW; subm Jan 1981 by PK and MW. Cal AD 1680 (1685, $1730,1808,1931,1955) 1937$ at $1 \sigma$; cal BP $270(265,220,142,19,0) 13$ at $1 \sigma$. Comment: provides 2nd date for use of dryland agricultural complex 03-731 and shelter ( $c f$, Beta-2277).

General Comment: major dryland agricultural complex, Site 03-731 covers ca 0.4 ha along 2 nd major ridge $W$ of Kawela Gulch at ca $90 \mathrm{~m}$ asl. Dryland crops, such as sweet potato (Ipomoea $\mathrm{sp}$ ) and gourd (Lagenaria sp), may have been cultivated in rocky terrain. Complex consisted of $>400$ stone mounds from field clearance and 2 substantial temporary habitation shelters which yielded occupation dates (Beta-2277, -2279) from Proto-Historic period.

Beta-3362. Kawela

Wood charcoal, 15.4g, from rockshelter Site 04-710, (Feature 51), architectural component 2, SW $1 / 4$ of Unit 13 , St I, 6-9cm below surface; scoop hearth filled with ashy sediment, dispersed charcoal, marine invertebrates and fishbone. Coll Apr 1981 and subm Sep 1981 by MW. Cal AD $1689(1694,1722,1812,1859,1869,1921,1955) 1926$ at $1 \sigma$; cal BP 261 $(256,228,138,91,81,29,0) 24$ at $1 \sigma$. Comment: date for use of upland rockshelter, $1.4 \mathrm{~km}$ inland, and assoc barkcloth (tapa) found throughout upper layers and surface of cultural deposit.

\section{Coastal Kaunakakai series}

Three charcoal samples were coll from two coastal middens along broad alluvial flat E and W of Kaunakakai Stream. Sites 03-630 and 03-631 were used as bases for exploiting rich coastal flats and adjacent broad alluvial plain. Short-term occupation is documented by numerous scoop hearths, ovens and pit features assoc with marine invertebrates, fishbone and few artifacts. No evidence of permanent occupation, such as post molds and house foundations, were present. Beta-7564 dates earliest use of 
any coastal dune along $\mathrm{S}$ coast and establishes date prior to inception of drastic environmental degradation initiated by burning adjacent uplands for agriculture. Beta-3802, -7563 and -7564 span Expansion period through early Proto-Historic period and fit well within expected age ranges for occupation of leeward Moloka'i. Upper cultural strata of both sites were disturbed and portions removed during expansion of nearby town. Sites were buried under alluvium deposited by adjacent stream and were discovered by backhoe trenching.

\section{Beta-3802. Kaunakakai}

$110 \pm 50$

Wood charcoal from Site 03-631, Tr 6, St VII, 73-93cm below surface, from pit(?) in cultural stratum containing small amounts of marine invertebrates, fishbone, possible fire-cracked basalt and carbonized Aleurites moluccana seed endocarp. Coll and subm Nov 1981 by K Shun. Cal AD $1677(1706,1719,1814,1829,1879,1917,1955) 1955$ at 1 ; cal BP 273 $(244,231,136,121,71,33,0) 0$ at $1 \sigma$. Comment: coastal dune midden Site 03-631 is W of Kaunakakai Stream, $120 \mathrm{~m}$ from shoreline at $2 \mathrm{~m}$ asl. Sample was coll below water table and seawater percolation may have effected accuracy of dates (Shun, 1982). Older end of age range is not unusual for stratigraphic position of sample. Sample weight not reported.

\section{Beta-7563. Kaunakakai}

$290 \pm 60$

Charcoal, 27.3g, from Site 03-630, Tr 2, Test Pit 4, Layer IIc, Level 5, $55-62 \mathrm{~cm}$ below surface, Feature 1 from small oven filled with dense charcoal, marine shell and fire-cracked vesicular basalt in calcareous sand matrix. Coll and subm Sep 1983 by J S Athens, Archaeol Consultant, Honolulu. Cal AD 1494 (1640) 1656 at $1 \sigma$; cal BP 456 (310) 294 at $1 \sigma$. Comment: this coastal dune is ca $250 \mathrm{~m}$ from shoreline at $2 \mathrm{~m}$ contour. Sample documents temporary use of coastal midden.

\section{Beta-7564. Kaunakakai}

$710 \pm 50$

Charcoal, 22.5g, from Site 03-630, Tr 16, Layer IIc, $60-65 \mathrm{~cm}$ below surface, Feature 1 from small oven filled with charcoal and fire-cracked vesicular basalt in calcareous sand matrix. Coll and subm Sep 1983 by JSA. Cal AD 1262 (1280) 1285 at $1 \sigma$; cal BP $688(670) 665$ at $1 \sigma$. Comment: dates temporary use of site.

\section{Upland Kaunakakai series}

Four wood charcoal samples were coll from three sites in dryland agricultural zone $1.1 \mathrm{~km}$ from coast. Zone, from $40-70 \mathrm{~m}$ asl, is situated on both sides of Kaunakakai Gulch on gently sloping, weakly dissected uplands. Ca 37.5ha on E side of gulch contains several field shelters and thousands of stone mounds (which resulted from prehistoric field clearance) (Weisler, 1989). This site complex is largest, securely dated, prehistoric dryland agricultural zone on Moloka'i. Results from three field shelters are assumed to date use of adjacent agric features. All samples coll and subm Aug 1988 by MW. 
Beta-27390. Kaunakakai

Wood charcoal, $6.4 \mathrm{~g}$, from agricultural Site 03-886, C-shaped shelter Feature B, W $1 / 2$ of slab-lined fireplace, $15-20 \mathrm{~cm}$ below surface. Fireplace contained fire-cracked vesicular basalt, charcoal and two layers of dense ash (representing individual firings) separated by culturally sterile sediment. Cal AD $1455(1525,1563,1628) 1650$ at $1 \sigma$; cal BP 495 (425, 387, $322) 300$ at $1 \sigma$. Comment: sample consisted of charcoal pieces $<7 \mathrm{~mm}$ max length. Date from lowest firing in fireplace and use of field shelter. Shelter is in middle of agric field; date suggests use of this portion of complex.

\section{Beta-27391. Kaunakakai}

$560 \pm 110$

Wood charcoal, 2.6g, from agricultural Site 03-887, Tr 2, W face, St II, $6-14 \mathrm{~cm}$ below surface; dispersed throughout stratum. Cal AD 1280 $(1334,1338,1403) 1440$ at $1 \sigma$; cal BP $670(616,612,547) 510$ at $1 \sigma . \mathrm{Com}$ ment: only $0.34 \mathrm{~g}$ of carbon was left after pretreatment; thus, counting was extended to reduce statistical error. Sample consisted mostly of angular chunks of wood charcoal $<5 \mathrm{~mm}$ max length and few pieces of carbonized grass dispersed through St II, id as agric stratum. Culturally sterile subsoil is St III, while ca $5 \mathrm{~cm}$ of silt (St I) accumulated after abandonment of site.

\section{Beta-27392. Kaunakakai}

$$
160 \pm 60
$$

Wood charcoal, $10.0 \mathrm{~g}$, from agricultural Site 03-887, circular enclosed shelter Feature A, W $1 / 2$ of fireplace, filled with dense ash and dispersed charcoal, few pieces of marine shellfish. Cal AD $1658(1678,1739$, $1804,1938,1955) 1955$ at $1 \sigma$; cal BP $292(272,211,146,12,0) 0$ at $1 \sigma$. Comment: sample consisted of angular chunks of wood charcoal $<7 \mathrm{~mm}$ max length with some carbonized grass. Probable id by MW of native Hawaiian tree (Erythrina sandwicensis; wiliwili) from at least one charcoal piece. Date is 2nd from Site 03-887 ( $c f$, Beta-27391) and suggested use of agricultural complex for perhaps $400 \mathrm{yr}$ from late 13th century through Proto-Historic period.

\section{Beta-27393. Kaunakakai}

$350 \pm 80$

Wood charcoal, 5.1g, from agricultural Site 03-888, circular shelter Feature A, W $1 / 2$ of slab-lined fireplace, $10-15 \mathrm{~cm}$ below surface. Fireplace filled with ash, fire-cracked vesicular basalt and charcoal lens at base. Cal AD $1441(1494,1502,1506,1605) 1645$ at $1 \sigma$; cal BP $509(456,448,444,345)$ 305 at $1 \sigma$. Comment: possible id of Erythrina sandwicensis from sample which included angular chunks of wood charcoal $<5 \mathrm{~mm}$ max length. Sample provided date for use of shelter and lowest extent of upland agricultural zone near $40 \mathrm{~m}$ contour.

General Comment: precise dating of agricultural sites remain, by their very nature, problematic. For example, gardening strata were continually reworked over course of use by constant addition of new sources of ${ }^{14} \mathrm{C}$ from crop plants, mulch and successive burning of dryland fields $(c f$, Handy, 1940; Yen, 1974). Thus, charcoal dispersed through gardening stratum (eg., Beta-27391) more accurately represents average age of multiple periods of use. This is in contrast to dates from discrete, charcoal layers 
within circumscribed slab-lined fireplaces, which were periodically cleaned and thus are more closely assoc with last use by inhabitants (Dean, 1978). This may, in part, account for difference in results between Beta-27391 (cal AD 1280, oldest end of range) which was dispersed through gardening stratum, and Beta-27390 (cal AD 1455), -27392 (cal AD 1658), and -27393 (cal AD 1441) each recovered from fireplace. It appears that agricultural zone on E side of Kaunakakai Gulch (Sites 03-886, -887, -888) was used as carly as late 13 th century (Early Expansion period) and into beginning of Proto-Historic period.

\section{3-312, Kalawao, Kalaupapa Peninsula, series}

Kaupikiawa Cave (Site 03-312), is near NE extent of Kalaupapa Peninsula, $0.5 \mathrm{~km} \mathrm{~W}$ of rocky coast at $15 \mathrm{~m}$ asl. Dense shellfish scatter with historic and prehistoric artifacts are found on surface of collapsed lava tube and extend to ca $45 \mathrm{~cm}$ below surface. Total site area is ca $300 \mathrm{~m}^{2}$. Site was test excavated for four days in 1966 and 1967 by Univ of Hawai'i field school (Pearson et al, 1974; Somers, 1985, p 42-43). Few excavation records exist and no stratigraphic profiles were drawn (R Pearson, pers commun, 1983). However, site was re-examined by MW and GF Somers, Natl Park Service, Honolulu, in 1984 and provenience of ${ }^{14} \mathrm{C}$ samples were considered accurate. Whether samples were from well-defined hearths or from other charcoal concentrations within deposits is uncertain. Three wood charcoal samples were subm for radiometric dating and document intermittent occupation of shelter beginning in 11 th century AD (Beta-9276 and -9962) to well into Historic period.

\section{Beta-9276. Kalawao}

$880 \pm 70$

Wood charcoal, 25.5g, from Site 03-312, Sq 7, Layer D, 23-30cm below surface, possibly from hearth or dispersed through dense midden. Coll Nov 1966 by RP. Subm Apr 1984 by GFS. Cal AD 1031 (1161, 1185) 1225 at $1 \sigma$; cal BP $919(789,765) 725$ at $1 \sigma$. Comment: 2nd oldest date for Moloka'i; suggests use of Kalaupapa Peninsula during late Developmental (AD 600-1100) to early Expansion period (AD 1100-1650) for exploitation of coastal marine resources.

\section{Beta-9962. Kalawao}

$490 \pm 180$

Wood ash and wood charcoal, 38.1g, from Site 03-312, Sq 7, Layer D, $35.5 \mathrm{~cm}$ below surface, "top of reddish somewhat sterile level 5 ", (Pearson, 1966 , note on sample label); probably from hearth. Coll Nov 1966 by RP. Subm July 1984 by GFS. Cal AD 1280 (1426) 1635 at $1 \sigma$; cal BP 670 (524) 315 at $1 \sigma$. Comment: only $0.17 \mathrm{~g}$ of carbon obtained after pretreatment; thus, counting was extended to reduce statistical error ( $M$ Tamers, pers commun, 1984). Sample subm to corroborate age of Beta-9276 which overlaps at $2 \sigma$. Beta-9962 dates occupation at or near base of cultural deposit.

Beta-9275. Kalawao

Wood charcoal, 21.3g, from Site $03-312$, Sq 3, Layer 5, 30-38cm below surface, possibly from hearth or dispersed through dense midden deposit. Coll Nov 1966 by RP; subm Apr 1984 by GFS. Cal AD 1689 (1694, 
$1722,1812,1859,1869,1921,1955) 1926$ at $1 \sigma$; cal BP $261(256,228$, $138,91,81,29,0) 24$ at $1 \sigma$. Comment: considered excellent sample composed of relatively large chunks of wood charcoal. Young age and relatively deep stratigraphic position seem incongruous, but charcoal may be intrusive into this level, possibly as part of pit feature. No historic artifacts were recovered at this level suggesting older range of dates is reliable.

\section{3-801, Kalama'ula series}

Site 03-801 consists of several habitation structures and assoc gardening features covering ca lha of leeward slopes of central Moloka'i, $1.5 \mathrm{~km}$ from coast at $45 \mathrm{~m}$ contour. Site was probably used intermittently for gardening (Athens, 1985) during Early and Late Expansion periods (AD $1100-1650$ ). One shell and 4 wood charcoal samples were coll and subm 1984 to 1985 by JSA.

Beta-11172. Kalama'ula

$1450 \pm 60$

Marine shell (Tellina palatam), 77.7g, from Site 03-800, Feature 12, Feature B (habitation terrace contiguous to Feature A discussed below), Test Pit 8, St III, 32-43cm below datum; shell lens of whole bivalves resting on non-cultural subsoil. Cal AD 1011 (1059) 1172 at $1 \sigma$; cal BP 939 (891) 778 at $1 \sigma$. Comment: $\Delta \mathrm{R}$ of $115 \pm 50$ used to calibrate shell sample (Stuiver, Pearson \& Braziunas, 1986) as sample derived from marine reservoir. (See also section on geologic samples for discussion of modern shell date.)

Three samples were subm from Feature 12, Terrace A, structure with three contiguous terraces at $\mathrm{S}$ extent of Site 03-800.

Beta-11171. Kalama'ula

$400 \pm 60$

Charcoal, $8.1 \mathrm{~g}$, from Test Pit 7, St I, $22-29 \mathrm{~cm}$ below datum, base of cultural deposit; oven filled with abundant fire-cracked vesicular basalt in matrix of ash and silt. Cal AD 1434 (1450) 1619 at $1 \sigma$; cal BP 516 (500) 331 at $1 \sigma$. Comment: date for probable, short-term occupation of habitation terrace.

Beta-11168. Kalama'ula

$300 \pm 60$

Charcoal, 34.6g, from Test Pit 3, St III $/ 2,68-88 \mathrm{~cm}$ below datum; oven with abundant charcoal chunks, grayish sediment and fire-cracked vesicular basalt. Cal AD $1490(1532,1541,1637) 1653$ at $1 \sigma$; cal BP 460 $(418,409,313) 297$ at $1 \sigma$. Comment: date for short-term occupation of habitation terrace.

Beta-11169. Kalama'ula

$\mathbf{7 0} \pm \mathbf{5 0}$

Charcoal, $10.5 \mathrm{~g}$, from Test Pit 4, St IIb, $38-51 \mathrm{~cm}$ below datum; possible post hole or pit filled mostly with coral and charcoal chunks, some marine shell and bone in silt matrix. Cal AD $1692(1903,1905,1955) 1955$ at $1 \sigma$; cal BP $258(47,45,0) 0$ at $1 \sigma$. Comment: date for feature which may be post hole or pit.

General Comment: three dates, discussed above, document short-term use of habitation terrace from 15th-17th centuries of Late Expansion period. 
Results fit Kirch's (1985) model of cultural evolution in Hawai'i, ie, less agriculturally productive areas of Hawaiian Islands (eg, leeward Moloka'i) were not utilized until relatively late in prehistoric sequence.

\section{Beta-11170. Kalama'ula}

Charcoal, 14.7g, from Site 03-800, C-shaped shelter (Feature 9), Test Pit 5, N extension, St II/I, 23-29cm below datum; Feature 1 probable hearth with oval lens of dark sediment with charcoal chunks. Cal AD 1663 $(1668,1751,1758,1777,1796,1947,1953) 1955$ at $1 \sigma$; cal BP 287 (282, $199,192,173,154,3,0) 0$ at $1 \sigma$. Comment: dated construction and use of shelter.

\section{3-885, Kipu series}

Two wood charcoal samples were acquired from buried site in uplands of central Moloka'i. Site 03-885, at base of unnamed gluch at $335 \mathrm{~m}$ asl, lies $1.5 \mathrm{~km}$ from sheer and inaccessible sea cliffs of $\mathrm{N}$ coast.

Beta-27115. Kipu

$500 \pm 70$

Wood charcoal, 20.3g, from Site 03-885, Tr 2, W face, St V, 130$155 \mathrm{~cm}$ below surface, dispersed throughout an oven feature containing marine shell, fishbone, fire-cracked vesicular basalt and few artifacts. Coll July 1988 and subm Aug 1988 by MW. Cal AD 1331 (1422) 1442 at $1 \sigma$; cal BP 619 (528) 508 at $1 \sigma$. Comment: along with Beta-27116 dates initial burning of forested uplands in Kipu area ostensibly to clear land for dryland agriculture. Also establishes approximate sedimentation rate for $120 \mathrm{~cm}$ of overburden covering St V.

Beta-27116. Kipu

$610 \pm 60$

Wood charcoal, 52.1g, from Site $03-885$, Tr 2, E face, St V, 120$135 \mathrm{~cm}$ below surface, dispersed through sandy silt matrix, ca $200 \mathrm{~cm}$ from oven (discussed above). Coll July 1988 and subm Aug 1988 by MW. Cal AD $1283(1321,1367,1388) 1408$ at $1 \sigma$; cal BP $667(629,583,562) 542$ at $1 \sigma$. Comment: overlaps with Beta-27115 at $2 \sigma$ and corroborates date for initial burning of Kipu forest.

General Comment: although depth of Beta-27115 and -27116 vary slightly, they provide independent support for initial burning of forested Kipu uplands during Early Expansion period.

\section{Kaluako'i series}

Land division of Kaluako'i encompasses ca 20,000ha of leeward W Moloka'i, approximately $\mathrm{W} 1 / 3$ of island. Dominated by Maunaloa volcano, its two rift zones (trending NW and SW) descend gently towards rocky coastlines with sheltered embayments. One fishbone and 6 charcoal samples are discussed from 5 sites along coast and 1 atop Maunaloa.

Beta-20906. Kawa'aloa Bay

$1290 \pm 60$

Fishbone (Kuhlia sandvicensis) 500g, from Site 02-21, pit feature containing predominately fishbone, with much lesser amounts of turtle and 
birdbone. Site is atop sterile, strongly cemented coralline sand, exposed at ground surface. Coll Apr 1984 by MW and S Collins. Subm Apr 1987 by MW. Cal AD 1176 (1255) 1296 at $1 \sigma$; cal BP 774 (695) 654 at $1 \sigma$. Comment: feature is probably part of midden extending from rockshelter located to NW. Pit clearly documents bones of endemic Hawaiian goose (Nesochen sandvicensis), historically unknown on Moloka'i, and prehistoric cultural material. Ocean reservoir effect was calculated as sample material derived from marine environment. A $\Delta \mathrm{R}$ factor of $115 \pm 50$, suggested for Hawaiian samples (Stuiver, Pearson, \& Braziunas, 1986, p 995), was used for calibration.

\section{Beta-13743. Mo'omomi}

$360 \pm 50$

Wood charcoal, 27.7g, from Site 02-24, Sq E6, 41-46cm below surface, in extremely dense stratum of basalt debitage, $15-30 \mathrm{~cm}$ thick; sample probably dispersed through level. Coll Aug 1952 by WJ Bonk, Univ Hawai' i; subm Aug 1985 by MW and T S Dye, formerly Bishop Mus. Cal AD 1445 (1490) 1635 at $1 \sigma$; cal BP $505(460) 315$ at $1 \sigma$. Comment: Site 02-24, $0.5 \mathrm{~km} \mathrm{~S}$ of coast at $15 \mathrm{~m}$ asl, is natural shelter $\left(\mathrm{ca} 15 \mathrm{~m}^{2}\right)$ in lithified dune excavated in 1952 (Bonk, 1954). Dates initial use of rock shelter occupied by persons for reducing fine-grained basalt into adze blanks and preforms. Provides indirect date for use of Mo'omomi Adze Quarry (02-29), ca $0.7 \mathrm{~km}$ SW.

\section{Beta-13744. 'Amikopala}

Wood charcoal, $31.4 \mathrm{~g}$, from habitation Site $02-85$, NE $1 / 3$ of slab-lined fireplace, $10-28 \mathrm{~cm}$ below surface; sample dispersed through stratum containing fire-cracked basalt in silt matrix. Coll July 1985 and subm Aug 1985 by MW and TSD. Cal 1528 (1648) 1662 at $1 \sigma$; cal BP 422 (302) 288 at $1 \sigma$. Comment: date for occupation of 'Amikopala summit region (Dye, Weisler \& Riford, 1985). Although site is in 'Amikopala Quarry complex, assoc of this date with adze production is unclear.

Beta-5700. Kawa'aloa Bay

Charcoal, 17.1g, from Site 02-629, dispersed through Feature A (cultural stratum with few basalt flakes, marine invertebrates and fishbone). Coll Oct 1982 by MW and SC; subm 1983 by SC. Cal AD $1673(1678,1739$, $1804,1938,1955) 1943$ at $1 \sigma$; cal BP $277(272,211,146,12,0) 7$ at $1 \sigma$. Comment: site lies in large dune of loose, calcareous sand $225 \mathrm{~m} \mathrm{SE}$ of Kawa'aloa Bay at ca $6 \mathrm{~m}$ asl. There was no evidence for historic use and 02629 may represent series of late prehistoric occupations.

\section{Beta-20881. Kawakiu Nui}

$170 \pm 60$

Wood charcoal, 23.8g, from Site 01-1610, Feature A, St III, $45 \mathrm{~cm}$ below surface at base of wave-cut exposure; sample dispersed through cultural stratum, $15 \mathrm{~cm}$ thick, with dense marine shellfish, fishbone, firecracked vesicular basalt and basalt flakes in silty-sand matrix. Coll Feb 1987 and subm Apr 1987 by MW. Cal AD 1655 (1674, 1743, 1801, 1941, 1955) 1955 at $1 \sigma$; cal BP $295(276,207,149,9,0) 0$ at $1 \sigma$. Comment: site is on $\mathrm{N}$ 
side of Kawakiu Nui Bay at end of eroding ridge. Sample provides 1 st ${ }^{14} \mathrm{C}$ result for entire W coast of Moloka'i (Weisler, 1987) and from its depth and lack of historical material, older end of age range most accurately dates site use.

\section{M-767. Kawa'aloa Bay}

$\mathbf{5 5 0} \pm \mathbf{3 0 0}$

Charcoal from Rockshelter 02-21, Sq F12, lowest cultural level, ca $1.1 \mathrm{~m}$ below surface. Coll Aug 1952 by WJ Bonk. Subm Jan 1959 by K P Emory, formerly Bishop Mus. Cal AD 1229 (1422) 1952 at $1 \sigma$; cal BP 721 (528) 0 at $1 \sigma$. Comment: Rockshelter 02-21 formed in lithified sand at $\mathrm{W}$ end of Kawa'aloa Bay, ca $15 \mathrm{~m}$ from ocean, at $3 \mathrm{~m}$ contour. Excavated by WJB Aug 1952 (Bonk, 1954). No other data available. Date was originally reported in Crane and Griffin (1959, p 195). See General Comment below.

\section{M-1183. Kalani}

$425 \pm 150$

Charcoal, 26.0g, from rockshelter $02-26$, Sq F12, bottom of concentrated cultural deposit of marine shell and fishbone, $61-76 \mathrm{~cm}$ below datum. Coll Aug 1952 by WJB; subm June 1959 by KPE. Cal AD 1330 (1442) 1640 at $1 \sigma$; cal BP 620 (508) 310 at $1 \sigma$. Comment: site located just before rocky coastline changes to precipitous cliffs, ca $15 \mathrm{~m}$ from coast at $10 \mathrm{~m}$ asl. Little data available. Solid carbon was probably used to analyze sample.

General Comment: according to Taylor (1987), solid carbon was used by W F Libby and other early researchers such as the Michigan lab, during the $1950 \mathrm{~s}$. These measurements resulted in "typical counting errors of 200 to 300 yrs for samples up to about 5000 yrs" (Taylor, 1987, p 82). Due to problems with sample contamination and detecting efficiency, results were often irreproducible. Determinations were frequently skewed toward too recent ages (Browman, 1981). Based on current knowledge of W Moloka'i settlement pattern chronology, age ranges of M-767 and -1 183 may be correct, but must be omitted from any discussion of prehistoric chronology.

It is interesting to note that the first ${ }^{14} \mathrm{C}$ sample analyzed from any Pacific island, one that "opened up undreamed of possibilities for reconstructing the prehistory of (Hawai'i)" (Emory, Bonk \& Sinoto, 1959, p vii), was analyzed by Libby at Chicago in 1951 using the solid carbon counting technique. Ironically, this important sample (C-540) should not be accepted as valid, although its reported long age span influenced a generation of archaeologists who had previously thought that Pacific archaeological sites were of much shorter duration and did not merit serious attention.

Four ${ }^{14} \mathrm{C}$ results for Kaluako'i span Early and Late Expansion periods (AD 1100-1650), and a 5th (Beta-5700) begins in the early Proto-Historic period. Two dates processed by the Michigan lab in the late 1950s (M-767, -1183) are considered invalid. Evidence for exploitation of coastal resources (shellfish, fish and turtle) and landbirds began toward the end of the 12 th century and continues today. The Mo'omomi Adze Quarry, one of 
the largest on the island, near the $N$ coast, was in use as early as the 15 th century. No sites were dated along the $S$ coast, and only one midden found on the W shore at Kawakiu Nui Bay was dated. A habitation complex near the summit region of Maunaloa at 'Amikopala, yielded a date from the 16 th-17th centuries. These dates conform to current models of Hawaiian settlement patterns (Hommon, 1986; Kirch 1985) in that settlements were dispersed through the windward regions in early prehistory, while the drier, leeward regions, such as W Moloka'i, were occupied relatively late, beginning in the Early Expansion period.

\section{GEOLOGIC SAMPLES}

Hawai'i

\section{Moloka'i Island}

\section{Beta-5122. Kawela}

Two pieces of branch coral (Porites sp), 28.2g, from Site 04-143, Auger Hole $10,40 \mathrm{~cm}$ below top of St III (marine stratum, non-cultural), $300 \mathrm{~cm}$ below surface. Coll Aug 1981 and subm Aug 1982 by MW. Cal BC 1255 (1122) 996 at $1 \sigma$; cal BP 3204 (3071) 2945 at $1 \sigma$. Comment: sample recovered from auger hole located ca $400 \mathrm{~m}$ inland from present shoreline, near sea level, on broad alluvial plain. Kakahai'a Fishpond lies immediately seaward. Coral sample was sharp, with no evidence of water-rounding, and assumed contemporaneous with deposition of marine stratum. Sample was pretreated by etching away outer layer with dilute acid; benzene synthesis and counting proceeded normally. $\Delta \mathrm{R}$ of $115 \pm 50 \mathrm{yr}$ (Stuiver, Pearson \& Braziunas, 1986) was used to calculate marine reservoir effect. Age of sample documented when present marsh surrounding Kakahai'a Pond was open to sea (Weisler, 1983). During Proto-Historic period (AD 1650-1795), Kawela area was intensively occupied (Weisler \& Kirch, 1985) and this coincided with human-induced shoreline progradation and later infilling of Kakahai'a Pond in 19 th century.

\section{Beta-12903. Puko'o}

$410 \pm 60$

$\delta^{13} C=-1.12 \%$

Marine shell (Tellina palatam), 34.6g, “from Moloka'i: Puko'o, from sandy mud, 6 inches to 2 feet down" (Athens, 1983, p 89). Coll 1905 by Langford and Thaanum. Subm 1983 by JSA. Cal AD 1955 (1955) 0 at $1 \sigma$; cal BP $0(0) 1950$ at $1 \sigma$. Comment: sample subm to provide $\Delta \mathrm{R}$ for marine reservoir effect for cultural sample Beta-11172, above (Kalama'ula). This sample varies considerably from L-576J (Stuiver, Pearson \& Braziunas, 1986, p 1020) as $629 \pm 51$, or Beta- 14024 .

\section{GX-2672. Kalani}

Fossil landsnail shells from lithified reddish fine-grained soil bed, 15$30 \mathrm{~cm}$ thick, lying unconformably on lower eolianite (Stearns, 1973, p 160). Soil layer is $1 \mathrm{~km} \mathrm{~W}$ of Kaiehu Point, $2 \mathrm{~m}$ asl at top of coralline sand beach. Stratum contains abundant calcareous root casts indicating soil bed supported dense vegetation. Coll by J Aidem ca 1970; subm ca 1970 by H T Stearns, formerly U S G S. Comments: ca $10 \mathrm{~g}$ of sample remained after ultra- 
sonic cleaning and dilute $\mathrm{HCl}$ leach (H Krueger, pers commun, 1988); (HTS): date is consistent with similar fossil land snails $61 \mathrm{~cm}$ above. Age and position of stratum suggest climatic and environmental conditions vastly different from present.

\section{ACKNOWLEDGMENTS}

In 1980, Patrick Kirch (formerly, B P Bishop Museum) provided the initial opportunity to begin what has developed into a long-term involvement with Moloka'i archacology. Many of the ${ }^{14} \mathrm{C}$ samples submitted during 1980 to 1985 were collected from field projects conducted under the auspices of the B P Bishop Museum, Honolulu, while the author was on the staff of the Department of Anthropology. Much of the archival data were collected at this time. Federal Grants-in-Aid support to the author (and P Cleghorn) provided funds, in 1985, through the Bishop Museum for dating two samples from West Moloka'i. Gary Somers (National Park Service, Honolulu) arranged travel expenses to visit sites at the Kalaupapa Peninsula and funds for dating three samples from Kaupikiawa Cave. Through archaeological contracts with the author and Randolf Moore (Moloka'i Ranch Ltd), Jim Kingzett (Moloka'i Golf Inc), and Phillip Boydston (Kaluako'i Corp), funding for many samples submitted during 1985 to 1988 was obtained.

Several contract reports and other site information were made available by Stephen Athens (Archaeological Consultant, Honolulu) and Annie Griffin, Historic Sites Division, Department of Land and Natural Resources, Honolulu. Requests for data on sample analyses were promptly answered by Kunihiko Kigoshi (Gakushuin), Harold Krueger (Geochron), and Jerry Stipp and Murry Tamers (Beta Analytic Inc).

At the University of Washington, comments on earlier versions of this paper were made by Patrick Kirch, Minze Stuiver, Donald Grayson, Robert Wenke and Kris Wilhelmsen. Minze Stuiver kindly provided an updated version of the microcomputer calibration program and answered several questions that archaeologists often confront while trying to interpret archaeological radiocarbon age determinations. I thank all of the above for their help and absolve them from any shortcomings found herein.

\section{REFERENCES}

Athens, I S, (ms) 1983, Archaeological and historical investigations at a property near Kaunakakai wharf, island of Molokai, Hawaii: Ms on file, State Hist Preservation Office, Dept Land \& Nat Resources, Hawai'i. (ms) 1985. Prehistoric investigations at an upland site on the leeward slopes of central Molokai: Ms on file, State Hist Preservation Office, Dept Land \& Nat Resources, Hawai'i.

Bonk, W J, (ms) 1954, Archaeological investigations on west Molokai: MA thesis, Univ Hawai'i, Honolulu.

Browman, D L, 1981, Isotopic discrimination and correction factors in radiocarbon dating, in Schiffer, M B, ed, Advances in archaeol method and theory: New York, Academic Press, p 221-295.

Butler, V L and Stein, J K, 1988, Comment on "Changing late Holocene flooding frequencies on the Columbia River, Washington”: Quaternary Research, v 29, no. 1, p 186-187.

Collins, S, (ms) 1983, Archaeological investigations of site 50-Mo-B6-80, Moloka'i island: Ms on file, Bishop Mus, Honolulu.

Crane, H R and Griffin, J B, 1959, University of Michigan radiocarbon dates IV: Am Jour Science Radiocarbon Supp, v 1, p 195.

Dean, I S, 1978, Independent dating in archaeological analysis, in Schiffer, M B, ed, Advances in archaeol method and theory: New York, Academic Press, p 223-255. 
Dye , T, Weisler, $M$ and Riford, M (ms) 1985, Adz quarries of Moloka'i and Oahu, Hawaiian Islands: Ms on file, Bishop Mus, Honolulu.

Emory, K P, Bonk, W J and Sinoto, Y H, 1959, Hawaiian archaeology: fishhooks. Bishop Mus special pub no. 47 .

Grayson, D K, in press, The chronology of North American Late Pleistocene extinctions: Jour Archacol Sci.

Handy, E S C, 1940, The Hawaiian planter, vol 1, his plants, methods and areas of cultivation: Bishop Mus Bull 161 .

Hendren, G H, 1975, Excavation of eight inland prehistoric habitation sites, in Kirch $\mathrm{P}$ and Kelly, M eds, Prehistory and ecology of a windward Hawaiian valley: Halawa Valley, Molokai: Pacific Anthropol Rec no. 24, p $117-152$.

Hommon, R J, 1986, Social evolution in ancient Hawai'i, in Kirch, P, ed, Island societics, archacological approaches to evolution and transformation: Cambridge, Cambridge Univ
Press.

Kirch, P, 1975a, Report 1. Excavations at sites A 1-3 and A 1-4: Early settlement and ecology in Halawa Valley, in Kirch, $\mathrm{P}$ and Kelly, M, eds, Prehistory and ecology in a windward Hawaiian valley: Halawa Valley, Molokai: Pacific Anthropol Rec no. 24, p 17-70.

$1975 \mathrm{~b}$, Radiocarbon and hydration-rind dating of prehistoric sites in Halawa Valley, in Kirch, P and Kelly, M, eds, Prehistory and ecology in a windward Hawaiian valley: Halawa Valley, Molokai: Pacific Anthropol Rec no. 24, p 161-166.

1985, Feathered gods and fishhooks, an introduction to Hawaiian archaeology

Mead, J I and Meltzer, D J, eds, 1985, Environments and extinctions: man in late glacial North America: Center for Study of Early Man, Orono, Univ Maine

McCoy, P, 1977, The Mauna Kea adze quarry project: a summary of the 1975 field investigations: Jour Polynesian Soc, v 86, no. 2, p 223-244.

(Otlet, R L, 1979, An assessment of laboratory errors in liquid scintillation methods of ${ }^{14} \mathrm{C}$ dating, in Berger, $\mathrm{R}$ and Suess, $\mathrm{H} \mathrm{E}$, eds, Radiocarbon dating, Internatl ${ }^{14} \mathrm{C}$ conf, 9 th, Proc: Berkeley, Univ California Press, p 256-267.

Pearson, R, Hirata, J, Potts, L and Harby, F, 1974, Test pitting of cave 1, Kalaupapa peninsula, Molokai, Hawaii: New Zealand Archaeol Newsletter, v 17 , no. 1, p 44-49.

Polach, H A, 1976, Radiocarbon dating as a research tool in archaeology- $\mathrm{popes}$ and limitations, in Barnard, Noel, ed, Symposium on scientific methods of research in the study of ancient Chinese Bronzes and South East Asian metal and other archaeological artifacts, Proc: Australian Natl Univ, Dept Far Eastern Hist Pub.

Shun, K, (ms) 1982, Archacological reconnaissance survey and test excavations of the wastewater treatment facility area, Kaunakakai, Molokai: Ms on file, Bishop Mus, Honolulu.

Somers, G F, 1985, Kalaupapa, more than a leprosy settlement, archaeology at Kalaupapa natural hist park: Western archaeol Conservation Center, Pubs in anthropol no. 30 .

Stearns, H T, 1973, Geologic setting of the fossil goose bones found on Molokai island, Hawaii: Bishop Mus occasional paper v XXIV, no 10, p 155-163.

Stuiver, M, 1982, A high-precision calibration of the AD radiocarbon time scale: Radiocarbon, v 24 , no. 1, p $1-26$.

Stuiver, M, Pearson, G W and Braziunas, T, 1986, Radiocarbon age calibration of marine samples back to 9000 cal BP, in Stuiver, M and Kra, R S, eds, Internatl ${ }^{14} \mathrm{C}$ conf, 12 th, Proc: Radiocarbon, v 28, no. 2B, p 980-1021. Stuiver, $\mathrm{M}$ and Polach, H A, 1977, Discussion: Reporting of ${ }^{14} \mathrm{C}$ data: Radiocarbon, v 19 , no.
3, p 355-363.

Stuiver, $M$ and Reimer, P J, 1986, A computer program for radiocarbon age calibration, in Stuiver, $M$ and Kra, R S, eds, Internatl ${ }^{14} \mathrm{C}$ conf, 12th, Proc: Radiocarbon, v 28, no $2 \mathrm{~B}$, p $1022-1030$. Taylor, R E, 1987, Radiocarbon dating, an archacological perspective: Orlando, Florida, Aca-
demic Press.

Weisler, M, (ms) 1983, An archacological survey and geomorphological reconstructions of the Kakahai’a natl wildlife refuge, Kawela, Moloka'i, Hawaiian Islands: Ms on file, Bishop
Mus, Honolulu.

- - (ms) 1987, Inventory, significance, and management of the archacological resources of northwest Moloka'i, Hawaiian Islands: Ms on file, State Hist Preservation Office, Dept Land \& Nat Resources, Hawai'i.

Central Moloka' (ms) 1989, Archaeological investigations of the Kaunakakai field system, SouthHawai' Moloka'i: Ms on file, State Hist Preservation Office, Dept Land \& Nat Resources, Weisler, $\mathrm{M}$ an

Hawaiian Collins, S, (ms) 1988, A radiocarbon date for extirpated avifauna on Moloka'i,

slands: $m$ s in possession of authors.

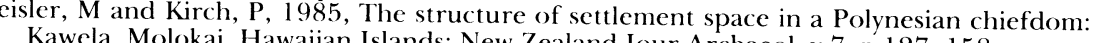

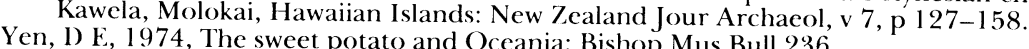

